\title{
Pemanfaatan Laboratorium Fisika dalam Pembelajaran Fisika, Studi Kasus di SMA Negeri 1 Sendawar dan SMA Negeri 1 Liggang Bigung Kabupaten Kutai Barat
}

\author{
Yuli Farida Istinganah ${ }^{1 *}$, Muliati Syam ${ }^{2}$, dan Zulkarnaen ${ }^{3}$ \\ $1^{*}, 2,3$ Program Studi Pendidikan Fisika, FKIP, Universitas Mulawarman \\ J. M. Yamin Samarinda, Kalimantan Timur, Indonesia \\ *E-mail: yulifrdaistinganah@gmail.com
}

\begin{abstract}
Abstrak
Penelitian ini bertujuan untuk mendeskripsikan pemanfaatan laboratorium fisika dan dalam pembelajaran fisika di SMA Negeri Kabupaten Kutai Barat. Analisis pemanfaatan laboratorium fisika ini ditinjau dari beberapa indikator yaitu: sarana dan prasarana, pemanfaatan laboratorium, kelengkapan dan ketersediaan alat, kegiatan praktikum, kondisi ruangan laboratorium, upaya yang dilakukan untuk memajukan pemanfaatan laboratorium, serta kontribusi laboratorium fisika terhadap pembelajaran fisika. Jenis penelitian yang digunakan adalah penelitian kombinasi (mixed methods). Sampel pada penelitian ini adalah 2 SMA Negeri di Kabupaten Kutai Barat. Hasil penelitian ini menunjukkan bahwa pemanfaatan laboratorium fisika sebagai sarana kegiatan praktikum di Kabupaten Kutai Barat tergolong dalam kategori kurang baik. Kontribusi laboratorium fisika dalam pembelajaran fisika masih kurang berkontribusi terhadap pembelajaran fisika.

Kata kunci: Pemanfaatan Laboratorium, kegiatan praktikum).
\end{abstract}

\section{Abstract}

This study aims to describe the use of the physics laboratory in learning physics at SMA Negeri Kutai Barat District. The analysis of the utilization of the physics laboratory is viewed from several indicators, namely: facilities and infrastructure, laboratory utilization, equipment and availability of tools, practicum activities, laboratory room conditions, efforts made to advance laboratory utilization, and the contribution of physics laboratories to physics learning. The type of research used is mixed methods. The samples in this study were 2 public high schools in Kutai Barat District. The results of this study indicate that the use of the physics laboratory as a facility for practicum activities in Kutai Barat District is in the unfavorable category. The contribution of the physics laboratory in learning physics still does not contribute to learning physics.

Keywords: Laboratory Utilization, practicum activities

Article History: Received: 20 Februari 2021 Accepted: 11 Maret 2021
Revised: 28 Maret 2021
Published: 30 April 2021

How to cite: How to cite: Istinganah, Y.F., Syam, M., Zulkarnaen.(2021). Pemanfaatan Laboratorium Fisika dalam Pembelajaran Fisika, Studi Kasus di SMA Negeri 1 Sendawar dan SMA Negeri 1 Liggang Bigung Kabupaten Kutai Barat. Jurnal Literasi Pendidikan Fisika, 2(1). pp. 23-33. Retrieved from http://jurnal.fkip.unmul.ac.id/index.php/JLPF

Copyright @ April 2021, Jurnal Literasi Pendidikan Fisika 
Pemanfaatan Laboratorium Fisika

\section{PENDAHULUAN}

Pendidikan di Negara Indonesia merupakan hal yang sangat penting, karena pendidikan merupakan hak dari setiap warga negaranya. Hal ini terlihat jelas dalam bunyi Pasal 31 ayat (1) UUD 1945 menyatakan bahwa "setiap warga Negara berhak mendapat pendidikan. Pemerintah terus berupaya meningkatkan mutu pendidikan pada tingkat dasar dan menengah di Indonesia, yaitu dengan menerapkan kurikulum 2013. Dalam menunjang mutu pendidikan di Indonesia, penyediaan sarana dan prasarana pembelajaran ditutut harus memadai, karena sarana dan prasarana pendidikan adalah komponen yang wajib ada dan sangatlah penting dimanfaatkan agar proses belajar mengajar dapat terlaksana secara optimal. Pemanfaatan sarana dan prasarana di sekolah salah satunya ialah pemanfaatan laboratorium. Hal ini juga diungkapkan oleh Rohmi dan Delsina (2019) bahwa selain faktor internal, faktor eksternal peserta didik juga sangat berkontribusi terhadap keberhasilan peserta didik dalam pendidikannya, salah satunya adalah sarana dan prasarana laboratorium. Indrawan (2015) mengungkapkan bahwa laboratorium adalah tempat untuk melaksanakan pembelajaran secara praktik yang membutuhkan peralatan khusus. Laboratorium adalah salah satu instrumen sekolah yang penting untuk menunjang pembelajaran agar proses pembelajaran menjadi lebih efektif. Menurut Wahyunidar (2017) laboratorium dapat memberikan dukungan terhadap pengetahuan dan pengertian para peserta didik tentang fakta, prinsip dan konsep. Pengetahuan dan penelitian dapat diperoleh dari berbagai sumber melalui kegiatan di laboratorium dan pengetahuan peserta didik dapat diperkuat. Laboratorium dapat pula memberi dukungan terhadap perkembangan, keterampilan, kebiasaan dan sikap peserta didik. Hal ini juga sependapat dengan Berliani (2019) bahwa dengan adanya laboratorium fisika, maka wawasan peserta didik semakin bertambah dan dapat menunjang pemahaman teori serta hasil belajar peserta didik.

Dengan adanya laboratorium fisika peserta didik dapat menggunakan alat laboratorium, mengolah pola pikir yang sistematis, memberikan pengalaman, dan ilmu yang mudah diingat, serta menjembatani konsep-konsep fisika dengan alat praktikum tersebut (Imastuti, 2016). Menurut Arifin, (2017) pemanfaatan laboratorium atau kegiatan praktikum adalah sebuah bagian dari proses belajar mengajar yang tidak dapat dipisahkan. Dengan praktikum, peserta didik mampu membuktikan konsep ataupun teori yang telah ada dan peserta didik dapat mengalami proses atau percobaan itu sendiri, serta peserta didik dapat membuat kesimpulan, dan menunjang pemahaman peserta didik terhadap materi pelajaran. Sehingga peserta didik menjadi lebih paham terhadap materi pelajaran dan hasil belajar pun dapat meningkat. Zikrika (2015) menjelaskan berdasarkan tingkat pemanfaatan laboratorium sebagai sumber belajar maka indikator-indikator yang harus ada, antara lain sebagai berikut:

1) Frekuensi penggunaan laboratorium.

2) Kelengkapan alat-alat dan bahan yang ada di laboratorium.

3) Kesesuaian materi dengan alat yang tersedia di laboratorium.

4) Alokasi waktu yang cukup untuk kegiatan praktikum.

Menurut Wahyunidar (2017) terdapat beberapa indikator pemanfaatan yang digunakan sebagai tolak ukur, antara lain sebagai berikut:

1) Saran prasarana, meliputi peralatan pendidikan berupa alat-alat kegiatan praktikum, prabot, media pendidikan, sumber belajar lain, bahan habis dipakai yang terdapat di laboratorium dan ruang laboratorium itu sendiri.

2) Pemanfaatan laboratorium dalam hal ini seperti penggunaan laboratorium yang efektif, frekuensi pemanfaatan laboratorium khususnya pelajaran fisika, pemanfaatan laboratorium sudah maksimal dalam menunjang pembelajaran fisika.

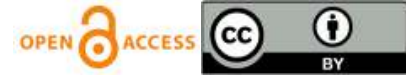


3) Kelengkapan dan kesesuaian alat berupa kelengkapan alat-alat yang ada di laboratorium, dan kesesuaian materi dengan alat yang tersedia di laboratorium.

4) Kegiatan praktikum seperti pelaksanaan praktikum di sekolah, apakah sudah sesuai dengan jadwal yang berlaku.

5) Kondisi ruang, bagaimana kondisi ruang laboratorium. Apakah sudah memenuhi kriteria laboratorium yang seharusnya.

6) Upaya, bagaimana upaya yang harus dilakukan untuk memajukan pemanfaatan laboratorium fisika di sekolah.

Dalam proses belajar mengajar di sekolah, peserta didik akan mendapatkan bekal ilmu teori dan praktik. Keduanya sangatlah penting untuk memberikan pemahaman secara konkret kepada peserta didik. Pada saat menyampaian setiap ilmu pengetahuan tidak boleh mengabaikan proses pembelajarannya. Sebagai lembaga penyelenggara pendidikan, sekolah memiliki peranan yang sangat besar dalam keberhasilan suatu pendidikan. Dari beberapa mata pelajaran di sekolah, fisika merupakan salah satu mata pelajaran yang membutuhkan teori dan praktik di sekolah.

Berdasarkan hasil observasi yang dilakukan penulis sebelum penelitian di Kabupaten Kutai Barat, penulis hanya mendapati dua sekolah yang memiliki sarana laboratorium fisika di sekolah yaitu SMA Negeri 1 Sendawar dan SMA Negeri 1 Linggang Bigung. Penulis menemukan beberapa fakta bahwa keberadaan laboratorium fisika di dua sekolah ini terkadang tidak digunakan sebagaimana fungsinya untuk tempat melakukan kegiatan praktikum bagi peserta didik dan pengelolaan terhadap laboratorium fisika tersebut terkesan masih kurang maksimal. Menyadari pentingnya sarana dan prasarana seperti laboratorium fisika dalam menunjang kegiatan pembelajaran di sekolah, oleh sebab itu diperlukan pengelolaan yang baik oleh pihak sekolah agar pemanfaatan laboratorium terlaksana secara efektif.

Pertanyaan yang muncul pada penelitian ini adalah "Bagaimana pemanfaatan laboratorium fisika sebagai sarana kegiatan praktikum dan kontribusi laboratorium fisika terhadap pembelajaran fisika di SMA Negeri 1 Sendawar dan SMA Negeri 1 Linggang Bigung?"

\section{METODE}

Jenis penelitian ini menggunakan metode penelitian kombinasi (mixed methods) antara metode kualitatif dan metode kuantitatif. Metode penelitian kualitatif yaitu pengumpulan data dari suatu latar alamiah bertujuan untuk menafsirkan fenomena-fenomena yang terjadi sebagai instrumen kunci, pengambilan sampel dari sumber data secara purposive dan snowbaal, teknik pengumpulan secara triangulasi (gabungan), analisis data yang bersifat kualitatif, dan hasil dari penelitian kualitatif lebih kepada makna dari pada generalisasi (Sari, 2020). Metode penelitian kuantitaif merupakan pendekatan untuk menguji berbagai teori dengan cara menelaah hubungan dari antar variabel. Biasaya variabel ini diukur dengan menggunakan instrumen penelitian yakni, angket, wawancara tersusun sehingga data hanya terdiri dari angka-angka yang dapat dianalisis melalui perhitungan statistik (Rukminingsih, 2020). Metode penelitian kombinasi bertujuan untuk mengetahui dan mendeskripsikan level pemanfaatan laboratorium fisika sebagai sarana kegiatan praktikum dan kontribusi laboratorium fisika terhadap pembelajaran. Populasi dalam penelitian ini adalah SMA Negeri 1 Sendawar dan SMA Negeri 1 Linggang Bigung Kabupaten Kutai Barat.

Cara menganalisis data kuantitatif yaitu dengan menggunakan instrument wawancara, kemudian dari hasil jawaban narasumber peneliti akan menggolongkan masing masing indikator yang terpenuhi ke dalam beberapa kategori. Setelah mendapatkan data kuantitatif di atas peneliti melanjutkan penelitian lebih dalam dengan metode kualitatif, hal ini dilakukan guna mendapatkan informasi lebih dalam mengenai pemanfaatan laboratorium fisika sebagai sarana kegiatan praktikum dan kontribusi 
laboratorium fisika terhadap pembelajaran fisika. Adapun cara menganalisis data pada penelitian kualitatif ini adalah berpedoman pada data kuantitatif yang telah di peroleh lalu dilanjutkan dengan penggalian data melalui teknik wawancara semistruktur, Setelah data terkumpul maka akan ditarik kesimpulan secara deduktif, artinya menarik kesimpulan dari uraian pernyataan-pernyataan yang bersifat umum ditarik ke khusus, sehingga penyajian hasil penelitian mudah dipahami.

Indikator pemanfaaatan laboratorium fisika yang akan dikembangkan sebagai instrumen untuk pengambilan data meliputi: sarana dan prasarana di laboratorium, pemanfaatan laboratorium secara efektif dan maksimal, kelengkapan dan ketersediaan alat, kegiatan praktikum yang dilaksanakan sesuai jadwal yang berlaku, kondisi ruangan laboratorium, serta upaya yang dilakukan untuk memajukan pemanfaatan laboratorium.

Kriteria pemanfaatan laboratorium fisika yang digunakan sebagai pedoman untuk menjustifikasi hasil penelitian terdiri dari:

1. Sangat baik, dengan kriteria sebagai berikut:

a. Jika sarana dan prasarana seperti ketersedian alat dan bahan di laboratorium sudah sangat lengkap, sarana dan prasarana sangat mudah digunakan guru maupun peserta didik, dan mekanisme penggunaan sarana prasarana di laboratorium sangat mudah dipahami guru dan peserta didik.

b. Jika laboratorium sangat sering digunakan guru sebagai tempat kegiatan praktikum, dan laboratorium telah dimanfaatkan secara maksimal untuk menunjang pembelajaran fisika.

c. Jika kelengkapan alat di laboratorium sangat lengkap dan telah sesuai dengan materi yang diajarkan atau di praktikumkan.

d. Jika kegiatan praktikum telah berjalan dengan sangat baik sesuai jadwal.

e. Jika kondisi ruangan sudah sangat memenuhi kriteria laboratorium fisika yang seharusnya.

f. Jika pihak sekolah telah melakukan upaya agar laboratorium sekolah bisa lebih maju lagi seperti melengkapi sarana prasarana, alat dan bahan praktikum, dan lain sebagainya.

2. Baik, dengan kriteria sebagai berikut:

a. Jika sarana dan prasarana seperti ketersedian alat dan bahan di laboratorium sudah cukup lengkap, sarana dan prasarana cukup mudah digunakan guru maupun peserta didik, dan mekasnisme penggunaan sarana prasarana di laboratorium cukup mudah dipahami guru dan peserta didik.

b. Jika laboratorium lumayan sering digunakan guru sebagai tempat kegiatan praktikum, dan laboratorium telah dimanfaatkan cukup maksimal untuk menunjang pembelajaran fisika

c. Jika kelengkapan alat di laboratorium sudah cukup lengkap dan telah cukup sesuai dengan materi yang diajarkan atau di praktikumkan.

d. Jika kegiatan praktikum telah berjalan dengan baik sesuai jadwal.

e. Jika kondisi ruangan sudah mendekati kriteria laboratorium fisika yang seharusnya.

f. Jika pihak sekolah telah melakukan upaya agar laboratorium sekolah bisa lebih maju lagi seperti melengkapi sarana prasarana, alat dan bahan praktikum, dan lain sebagainya.

3. Cukup baik, dengan kriteria sebagai berikut:

a. Jika sarana dan prasarana seperti ketersedian alat dan bahan di laboratorium lumayan lengkap, sarana dan prasarana lumayan mudah digunakan guru maupun peserta didik, dan mekasnisme penggunaan sarana prasarana di laboratorium lumayan mudah dipahami guru dan peserta didik.

b. Jika laboratorium kurang sering digunakan guru sebagai tempat kegiatan praktikum, dan laboratorium kurang dimanfaatkan untuk menunjang pembelajaran fisika.

c. Jika kelengkapan alat di laboratorium lumayan lengkap dan sebagian telah sesuai dengan materi yang diajarkan atau di praktikumkan.

d. Jika kegiatan praktikum belum berjalan dengan baik sesuai jadwal .

e. Jika kondisi ruangan belum mendekati kriteria laboratorium fisika yang seharusnya.

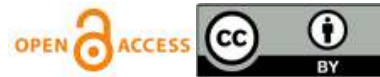


f. Jika pihak sekolah telah melakukan upaya agar laboratorium sekolah bisa lebih maju lagi seperti melengkapi sarana prasarana, alat dan bahan praktikum, dan lain sebagainya.

4. Kurang baik, dengan kriteria sebagai berikut:

a. Jika sarana dan prasarana seperti ketersedian alat dan bahan di laboratorium masih sangat terbatas, sarana dan prasarana sebagian mudah digunakan dan sebagian lagi tidak mudah digunakan guru maupun peserta didik, dan mekasnisme penggunaan sarana prasarana di laboratorium sebagian mudah dipahami dan sebagian lagi tidak mudah dipahami guru dan peserta didik.

b. Jika laboratorium jarang sekali digunakan guru sebagai tempat kegiatan praktikum, dan laboratorium kurang dimanfaatkan untuk menunjang pembelajaran fisika.

c. Jika kelengkapan alat di laboratorium masih sangat terbatas dan belum sesuai dengan materi yang diajarkan atau di praktikumkan.

d. Jika kegiatan praktikum tidak terjadwal dengan baik.

e. Jika kondisi ruangan masih jauh dari kriteria laboratorium fisika yang seharusnya.

f. Jika pihak sekolah kurang melakukan upaya agar laboratorium sekolah bisa lebih maju lagi seperti melengkapi sarana prasarana, alat dan bahan praktikum, dan lain sebagainya.

Teknik pengumpulan data yang digunakan oleh peneliti yaitu wawancara kepada guru yang ditugaskan sebagai kepala laboratorium fisika, observasi dan dokumentasi ditinjau dari indikator pemanfaatan laboratorium fisika yaitu sarana dan prasarana laboratorium, pemanfaatan laboratorium, kelengkapan dan kesesuaian alat di laboratorium, kegiatan praktikum, kondisi ruang, dan upaya yang dilakukan sekolah untuk memajukan laboratorium serta kontribusi laboratorium fisika terhadap pembelajaran fisika bagi guru di setiap sekolah.

Pada penelitian ini, peneliti menggunakan teknik analisis data sebagai berikut ini:

1. Analisis Hasil Data Wawancara

Dalam penelitian ini yang menjadi responden dalam pengumpulan data wawancara adalah guru yang ditugaskan sebagai kepala laboratorium fisika. Hasil wawancara yang akan di analisis peneliti meliputi sarana dan prasarana laboratorium, pemanfaatan laboratorium, kelengkapan dan kesesuaian alat di laboratorium, kegiatan praktikum, kondisi ruang, dan upaya yang dilakukan sekolah untuk memajukan laboratorium serta kontribusi laboratorium fisika terhadap pembelajaran fisika bagi guru di setiap sekolah.

2. Analisis Hasil Observasi

Berdasarkan pedoman observasi yang telah peneliti buat dapat dilihat bahwa observasi dibagi menjadi 7 point, yakni 1) fasilitas ruang laboratorium, 2) pemanfaatan laboratorium fisika melalui pelaksanaan praktikum fisika, 3) inventaris alat dan bahan laboratorium fisika, 4) penjadwalan laboratorium fisika digunakan sebagai sarana kegiatan praktikum, 5) kondisi sarana prasarana dan kelengkapan ruang laboratorium fisika, 6) upaya sekolah untuk memajukan laboratorium fisika, 7) serta kontribusi laboratorium fisika terhadap pembelajaran fisika bagi guru dan siswa di setiap sekolah.

3. Analisis Data Dokumentasi

Dokumentasi dalam penelitian ini meliputi foto keadaan ruangan laboratorium fisika, struktur organisasi laboratorium fisika, daftar inventaris alat dan bahan laboratorium fisika, serta wawancara penelitian. Dokumentasi ini dijadikan sebagai bukti bahwa telah diadakan suatu penelitian yang sifatnya alamiah dan sesuai dengan konteks.

Setelah data terkumpul maka akan ditarik kesimpulan secara deduktif, artinya menarik kesimpulan dari uraian pernyataan-pernyataan yang bersifat umum ditarik ke khusus, berdasarkan predikat dari pemanfaatan penggunaan laboratorium sehingga penyajian hasil penelitian mudah dipahami 


\section{HASIL DAN PEMBAHASAN}

\section{HASIL}

Setelah dilakukan penelitian dengan melakukan wawancara kepada guru yang ditugaskan sebagai kepala laboratorium fisika, observasi dan dokumentasi maka diperoleh hasil pemanfaatan laboratorium sebagai sarana kegiatan praktikum di SMA Negeri 1 Sendawar dan SMA Negeri 1 Linggang Bigung Kabupaten Kutai Barat sebagai berikut:

Untuk sarana dan prasarana masuk kedalam kategori kurang baik karena ketersediaan alat dan bahan di laboratorium masih sangat terbatas, sarana dan prasarana sebagian mudah digunakan dan sebagian lagi tidak mudah digunakan guru maupun peserta didik, dan mekasnisme penggunaan sarana prasarana di laboratorium sebagian mudah dipahami dan sebagian lagi tidak mudah dipahami guru dan peserta didik. Untuk pemanfaatan laboratorium masuk kedalam kategori kurang baik karena laboratorium jarang sekali digunakan guru sebagai tempat kegiatan praktikum, dan laboratorium kurang dimanfaatkan untuk menunjang pembelajaran fisika. Untuk kelengkapan alat masuk dalam kategori kurang baik karena kelengkapan alat di laboratorium masih sangat terbatas dan belum sesuai dengan materi yang diajarkan atau di praktikumkan. Kegiatan praktikum masuk dalam kategori kurang baik karena kegiatan praktikum tidak terjadwal dengan baik. Untuk kondisi ruang masuk kedalam kategori kurang baik karena kondisi ruangan masih jauh dari kriteria laboratorium fisika yang seharusnya. untuk upaya masuk kedalam kategori kurang baik dikarenakan pihak sekolah kurang melakukan upaya agar laboratorium sekolah bisa lebih maju lagi seperti melengkapi sarana prasarana, alat dan bahan praktikum, dan lain sebagainya. Dan untuk kontribusi laboratorium fisika masuk kedalam kategori kurang berkontribusi terhadap pembaelajaran karena beberapa faktor ini belum terpenuhi yaitu, membantu guru dalam melatih keterampilan dan sikap ilmiah peserta didik, membantu guru dan siswa dalam menemukan dan pemecahan masalah untuk mengembangkan daya inovasi dan kreativitas peserta didik, serta membantu guru dalam meningkatkan motivasi peserta didik untuk memperdalam pengetahuan dari suatu fakta yang diselidiki atau diamatinya.

Tabel 1.1 Pemanfaatan Laboratorium Fisika

\begin{tabular}{llcc}
\hline No & Indikator pemanfaatan laboratorium fisika & \multicolumn{2}{c}{ kategori } \\
\hline \multicolumn{1}{l}{} & & SMA N 1 Sendawar & SMA N 1 Lingga Bigung \\
\hline 2 & Pemanfaatan Laboratorium & Kurang Baik & Kurang Baik \\
\hline 3 & Kelengkapan dan Kesesuaian Alat & Kurang Baik & Kurang Baik \\
\hline 4 & Kegiatan Praktikum & Kurang Baik & Kurang Baik \\
\hline 5 & Kondisi Ruang & Kurang Baik & Kurang Baik \\
\hline 6 & Upaya & Kurang Baik & Kurang Baik \\
\hline 7 & Kontribusi Laboratorium Fisika & Kurang Baik & Kurang Baik \\
\hline & & Kurang Berkontribusi & Kurang Berkontribusi \\
\hline
\end{tabular}

Pada tabel 1.1 tersebut, tiap indikator pemanfaatan laboratorium fisika dari SMA Negeri 1 Sendawar dan SMA Negeri 1 Linggang Bigung Kabupaten Kutai Barat dalam kategori kurang baik dan kurang berkontribusi terhadap pembelajaran fisika.

\section{PEMBAHASAN}

Tujuan penelitian ini yaitu untuk mengetahui dan mendeskripsikan pemanfaatan laboratorium fisika sebagai sarana kegiatan praktikum di SMA Negeri 1 Sendawar dan SMA Negeri 1 Linggang Bigung Kabupaten Kutai Barat. Penelitian ini dilakukan di SMA Negeri 1 Sendawar dan SMA Negeri 1 
Pemanfaatan Laboratorium Fisika

Linggang Bigung Kabupaten Kutai Barat. Pada indikator sarana dan prasarana di SMA Negeri 1 Sendawar dan SMA Negeri 1 Linggang Bigung berdasarkan hasil wawancara diperoleh informasi untuk ketersedian alat dan bahan, sudah cukup lengkap dan ada beberapa alat yang jumlahnya sudah mulai berkurang dan rusak, sedangkan dari hasil observasi di SMA Negeri 1 Sendawar ada beberapa fasilitas yang belum dimiliki oleh laboratorium, diantaranya adalah ruang persiapan, laboratorium belum memiliki wastafel/bak cuci untuk guru dan siswa mencuci tangan, laboratorium belum memiliki peralatan P3K, serta yang terakhir laboratorium belum memiliki alat pemadam kebakaran. Dan untuk hasil observasi di SMA Negeri 1 Linggang Bigung ada beberapa sarana dan prasarana yang belum dimiliki laboratorium, diantaranya ruang persiapan, peralatan P3K, serta belum memiliki alat pemadam kebakaran.

Pada indikator pemanfaatan laboratorium berdasarkan hasil wawancara yang dilakukan dengan guru kepala laboratorium SMA Negeri 1 Sendawar dan SMA Negeri 1 Linggang Bigung diperoleh informasi pemanfaatan laboratorium fisika sudah cukup efektif menyesuaikan dengan materi pembelajaran dan pemanfaatan laboratorium sudah dimanfaatkan secara maksimal untuk menunjang pembelajaran fisika, sedangkan dari hasil observasi dapat diketahui bahwa di SMA Negeri 1 Sendawar, masih banyak kegiatan praktikum yang tidak dapat dilaksanakan karena sekolah masih kekurangan alat dan bahan percobaan, diantaranya adalah percobaan pemuaian panjang dan gelombang mikro pada kelas $\mathrm{X}$, serta percobaan pipa organa terbuka dan tertutup pada kelas XII. Dan untuk hasil observasi di SMA Negeri 1 Linggang Bigung, masih banyak kegiatan praktikum yang belum dapat terlaksana karena masih kekurangan alat dan bahan percobaan, diantaranya adalah percobaan pemuaian panjang dan gelombang mikro pada kelas $\mathrm{X}$, dan percobaan mesin Adwood, percobaan gaya gesek Statis dan gaya gesek kinetis, dan percobaan gaya sentripetal pada kelas XI, serta percobaan pipa organa terbuka dan tertutup dan percobaan jembatan Wheatston pada kelas XII.

Pada indikator kelengkapan dan kesesuaian alat berdasarkan hasil wawancara yang dilakukan dengan guru kepala laboratorium SMA Negeri 1 Sendawar dan SMA Negeri 1 Linggang Bigung diperoleh informasi bahwa kelengkapan dan kesesuaian alat laboratorium fisika sudah cukup lengkap dan juga sudah sesuai, sedangkan berdasarkan hasil observasi diperoleh bahwa di SMA Negeri 1 Sendawar, banyak sekali alat dan bahan yang ditemukan dalam keadaan rusak ataupun tidak dapat digunakan lagi, diantaranya adalah pada kategori kit optika, rumah lampu bertangkai dengan lampu pijar yang berjumlah 10 buah didapati 2 buah telah rusak, kaki rel yang berjumlah 16 buah didapati 4 buah telah rusak, pada kategori listrik dan magnet, kapasitor yang berjumlah 6 buah didapati 2 buah telah rusak dan tidak dapat digunakan lagi, LDR yang satu-satunya dimiliki oleh laboratoriun didapati telah rusak, jembatan penghubung yang berjumlah 17 buah didapati 3 buah telah rusak, kabel penghubung merah yang berjumlah 7 buah didapati 1 buah telah rusak, pada kategori kit mekanika, resistor yang berjumlah 16 buah didapati 1 buah telah rusak, batang statif yang berjumlah 8 didapati 2 telah rusak, neraca pegas $3 \mathrm{~N}$ yang berjumlah 8 didapati berkurang 2 buah, pada kategori kit panas dan hidrostatiska, labu erlenmeyer yang berjumlah 4 buah didapati 1 buah telah rusak, pembakar spiritus yang berjumlah 4 buah didapati 1buah telah rusak, tabung reaksi yang berjumlah 2 buah didapati telah rusak semua, serta pada kategori perlengkapan lainnya seperti power supply yang berjumlah 17 buah didapati 2 buah telah rusak, dan audio generator yang berjumlah 4 buah didapati 2 telah rusak. Dan untuk hasil observasi di SMA Negeri 1 Linggang Bigung, banyak alat dan bahan laboratorium yang didapati dalam keadaan rusak atau tidak dapat digunakan lagi, diantaranya adalah pada kategori kit optika, lensa setengah lingkaran yang berjumlah 1 buah dan didapati telah rusak dan tidak dapat digunakan. Pada kategori kit listrik dan magnet, kumparan 1000 lilitan yang jumlah 6 buah didapati 1 buah rusak, Saklar 1 kutub yang berjumlah 10 buah didapat 4 buah rusak, potensiometer yang berjumlah 1 buah didapati telah rusak dan tidak dapat di gunakan lagi, kabel penghubung yang berjumlah 8 buah didapati 1 buah rusak, serta kabel penghubung hitam yang berjumlah 6 buah didapati 1 buah rusak. Pada katogori kit mekanika, dasar statif yang berjumlah 8

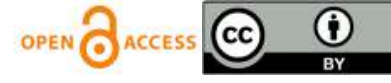


buah didapati 3 buah rusak, neraca pegas 1,5 $\mathrm{N}$ yang berjumlah 7 buah didapati 1 buah rusak, jepit penahan yang berjumlah 10 buah didapati 1 buah rusak, dan pegas spiral yang berjumlah 6 buah didapat 2 rusak. Serta pada kategori perlengkapan lainnya seperti jangka sorong yang berjumlah 3 buah didapati 1 buah rusak, amperemeter yang berjumlah 12 buah didapati 1 buah rusak, tekanan hidrostatik (alat peraga) yang berjumlah 1 buah didapati telah rusak dan tidak dapat digunakan lagi, dan hukum Ohm (alat peraga) yang berjumlah 6 buah didapati 2 rusak.

Pada indikator kegiatan praktikum berdasarkan hasil wawancara yang dilakukan dengan guru kepala laboratorium SMA Negeri 1 Sendawar dan SMA Negeri 1 Linggang Bigung diperoleh informasi bahwa kegiatan praktikum untuk setiap kelasnya sudah berjalan sesuai dengan jadwal yang berlaku, sedangkan berdasarkan hasil observasi diperoleh informasi bahwa di SMA Negeri 1 Sendawar, masih banyak praktikum yang belum dan tidak terlaksanakan, diantaranya pada kelas $10 \mathrm{mipa} / \mathrm{pis}$ hanya sampai materi pengukuran dengan frekuensi praktikum yang terlaksana 2 kali, pada kelas 11 mipa hanya sampai materi mesin Atwood dan gaya gesek statis dan gaya gesek kinetis dengan frekuensi praktikum seharusnya 2 kali tetapi yang terlaksana hanya 1 kali, serta pada kelas 12 mipa/pis hanya sampai materi hukum Ohm dengan frekuensi praktikum yang seharusnya 2 kali tetapi yang terlaksana hanya 1 kali dan materi gerak Harmonik pada bandul dengan frekuensi praktikum yang terlaksana 2 kali. Dan untuk hasil observasi di SMA Negeri 1 Linggang Bigung, masih banyak praktikum yang belum dan tidak terlaksanakan, diataranya pada kelas $10 \mathrm{mipa} / \mathrm{pis}$ hanya sampai materi pengukuran dan GLBB dengan frekuensi praktikum yang terlaksana seharusnya 2 kali tetapi yang terlaksna hanya 1 kali, pada kelas 11 mipa tidak terdapat kegiatan praktikum yang terlaksanakan, serta pada kelas $12 \mathrm{mipa} /$ pis hanya sampai materi hukum Ohm dengan frekuensi praktikum yang seharusnya 2 kali tetapi yang terlaksana hanya1 kali. Pada saat mendekati UNBK kelas XII, laboratorium fisika di SMA Negeri 1 Linggang Bigung dialih fungsikan menjadi laboratorium komputer, disebabkan karena kurangnya ruang laboratorium komputer pada sekolah ini. Serta masih banyak praktikum yang belum dan tidak terlaksanakan pada kedua sekolah ini, karena sekolah belum memiliki alat dan bahan serta pada saat ini masa pendemi covid-19 sehingga pembelajaran dilaksanakan secara jarak jauh (daring).

Pada indikator kondisi ruang laboratorium fisika di SMA Negeri 1 Sendawar di peroleh hasil wawancara bahwa kondisi ruang laboratorium jika dilihat dari segi kriteria laboratorium fisika yang seharusnya, dapat dikatakan belum memenuhi kriteria laboratorium sepenuhnya. Karena masih ada beberapa kekurangan. Dan berdasarkan hasil observasi dapat diketahui bahwa kondisi ruang laboratorium fisika belum sesuai dengan kriteria kerena masih banyak kelengkapan yang belum dimiliki oleh laboratorium, diantaranya adalah ruang persiapan, laboratorium belum memiliki wastafel/ bak cuci untuk siswa dan guru mencuci tangan, laboratorium belum memiliki Peralatan P3K, dan yang terakhir laboratorium belum memiliki alat pemadam kebakaran. selanjutnya, untuk kondisi ruang laboratorium fisika di SMA Negeri 1 Linggang Bigung berdasarkan hasil wawancara didapati bahwa jika dilihat dari segi kriteria laboratorium fisika yang seharusnya, dapat dikatakan sudah mendekati kriteria laboratorium yang seharusnya. akan tetapi dari hasil observasi yang dilakukan menemukan bahwa kondisi ruang laboratorium belum sesuai dengan kriteria sarana dan prasarana ruang laboratorium, karena ada beberapa sarana prasarana dalam kelengkapan ruang laboratorium belum di miliki oleh laboratorium fisika, diantaranya adalah belum memiliki meja laboratorium dengan kisaran ukuran panjang 200-500 cm, dengan lebar 60-150 cm, dan tinggi $75-90 \mathrm{~cm}$, belum memiliki peralatan P3K, belum memliki alat pemadam kebakaran, dan yang terakhir laboratorium belum memiliki jam dinding.

Pada indikator upaya yang dilakukan pihak sekolah dalam memajukan pemanfaatan laboratorium fisika di SMA Negeri 1 Sendawar, berdasarkan hasil wawancara diperoleh informasi bahwa pihak sekolah selalu mengupayakan pengadaan alat dan bahan yang dibutuhkan saat melakukan praktikum serta menyediakan sarana seperti kursi dan meja, sedangkan berdasarkan hasil observasi yang dilakukan didapati bahwa terdapat beberapa upaya yang tidak terealisasikan 
oleh pihak sekolah diantaranya mengupayakan ruang laboratorium fisika dapat memenuhi standar laboratorium fisika yang seharusnya, pengadaan alat peraga, pengadaan lemari bahan, pengadaan alat P3K, serta pengadaan alat pemadam. Selanjutnya, pada SMA Negeri 1 Linggang Bigung berdasarkan hasil wawancara diperoleh informasi bahwa pihak sekolah mengupayakan untuk menambah fasilitas alat-alat laboratorium fisika agar dapat menggunakan laboratorium semaksimal mungkin untuk meningkatkan pemahaman siswa, sedangkan dari hasil observasi dipeoleh informasi bahwa terdapat beberapa upaya yang tidak terealisasikan oleh pihak sekolah, diantaranya adalah mengupayakan ruang laboratorium fisika dapat memenuhi standar laboratorium fisika yang seharusnya, pengadaan meja kerja siswa, pengadaan alat dan bahan, pengadaan alat P3K serta pengadaan alat pemadam kebakaran.

Pada indikator kontribusi laboratorium fisika di SMA Negeri 1 Sendawar dan SMA Negeri 1 Linggang Bigung, berdasarkan hasil wawancara diperoleh informasi bahwa laboratorium fisika sudah sangat berkontribusi bagi guru dalam pembelajaran fisika. sedangkan berdasarkan hasil observasi yang diperoleh di SMA Negeri 1 Sendawar didapatkan bahwa laboratorium kurang berkontribusi bagi guru dalam pembelajaran fisika, diantaranya dalam hal membantu guru melatih keterampilan dan sikap ilmiah peserta didik, serta membantu guru meningkatkan motivasi peserta didik untuk memperdalam pengetahuan dari suatu fakta yang diselidiki atau diamatinya. Selanjutnya, untuk hasil observasi yang dilakukan di SMA Negeri 1 Linggang Bigung diperoleh informasi bahwa laboratorium kurang berkontribusi bagi guru dalam pembelajaran fisika, diantaranya dalam hal membantu guru dalam melatih keterampilan dan sikap ilmiah peserta didik, membantu guru dan siswa dalam menemukan dan pemecahan masalah untuk mengembangkan daya inovasi dan kreativitas peserta didik, serta membantu guru dalam meningkatkan motivasi peserta didik untuk memperdalam pengetahuan dari suatu fakta yang diselidiki atau diamatinya.

Pada penelitian ini, terdapat perbedaan dari hasil wawancara dan observasi bersama guru fisika dikedua sekolah tersebut. Hasil yang diperoleh dari wawancara menujukkan bahwa pemanfaatan laboratorium masuk kedalam kategori baik. Namun berbeda halnya dengan hasil observasi, guru tidak memberikan hasil yang sesuai kenyataan pada saat wawancara dimana pada hasil observasi ditemukan bahwa pada setiap indikator masih belum terpenuhi, seperti dalam sarana dan prasarana laboratorium belum memiliki ruang persiapan, ruang penyimpanan alat dan bahan, laboratorium belum memiliki wastafel/bak cuci untuk guru dan siswa mencuci tangan, laboratorium belum memiliki peralatan P3K, serta yang terakhir laboratorium belum memiliki alat pemadam kebakaran. Pada indikator pemanfaatan laboratorium ditemukan masih banyak kegiatan praktikum yang tidak dapat dilaksanakan karena sekolah masih kekurangan alat dan bahan percobaan serta melakukan pelatihan laboratorium. indikator kelengkapan dan kesesuaian alat terlihat banyak sekali alat dan bahan yang ditemukan dalam keadaan rusak ataupun tidak dapat digunakan lagi. Indikator kegiatan praktikum, ditemukan bahwa masih banyak praktikum yang belum dan tidak terlaksanakan hal ini dikarenakan padatnya materi pembelajaran fisika sehingga guru memilih metode ceramah, laboran yang membatu pelaksanaan praktikum dan ketersediaan alat dan bahan di laboratorium masih kurang. Indikator kondisi ruang laboratorium fisika belum sesuai dengan kriteria dan standar laboratorium fisika kerena masih banyak kelengkapan yang belum dimiliki oleh laboratorium, diantaranya adalah ruang persiapan, laboratorium belum memiliki wastafel/ bak cuci untuk siswa dan guru mencuci tangan, laboratorium belum memiliki Peralatan P3K, dan yang terakhir laboratorium belum memiliki alat pemadam kebakaran. indikator upaya yang dilakukan sekolah untuk memajukan pemanfaatan laboratorium terlihat bahwa terdapat beberapa upaya yang tidak terealisasikan oleh pihak sekolah. Serta pada indikator kontribusi laboratorium fisika terhadap pembelajaran fisika didapatkan bahwa laboratorium kurang berkontribusi bagi guru dalam pembelajaran fisika.

Hasil pada penelitian ini sejalan dengan penelitian yang dilakukan oleh Nursabiah dkk (2020) yang dimana dijelaskan bahwa frekuensi dalam memanfaatkan laboratorium sebagai sarana kegiatan praktikum masih sangat rendah, hal tersebut terjadi karena beberapa penyebab yang dialami oleh 
guru, sebagai berikut: (1) frekuensi guru dalam mengikuti pelatihan laboratorium masih terbilang rendah, (2) kelengkapan dan ketersediaan alat dan bahan praktikum masih kurang, (3) materi pembelajaran Fisika culup padat sehingga guru lebih memilih mengajar menggunakan metode ceramah, (4) tujuan dari pembelajaran fisika sulit tercapai melalui kegiatan praktikum, (5) tidak adanya laboran yang menolong dalam pelaksanaan kegiatan praktikum fisika.

Sehubung dengan diperolehnya hasil penelitian yang menggambarkan pemanfaatan laboratorium fisika sebagai sarana kegiatan praktikum di SMA Negeri 1 Sendawar dan SMA Negeri 1 Linggang Bigung Kabupaten Kutai Barat berada dalam kategori kurang baik. Melalui informasi tersebut, maka diharapkan dapat mengimplikasikan kepada pihak dinas pendidikan dan sekolah untuk lebih memperhatikan kualitas dan memenuhi atau melengkapi kekurangan-kekurangan pada pemanfaatan laboratorium fisika berdasarkan dari hasil observasi peneliti, serta kepada peneliti selanjutnya diharapkan hasil penelitian ini dapat dijadikan sebagai bahan rujukan dan pertimbangan, khususnya untuk melakukan penelitian serupa terutama tentang pemanfaatan laboratorium fisika.

\section{PENUTUP}

Berdasarkan penelitian dan analisis pemanfaatan laboratorium fisika sebagai sarana kegiatan praktikum di SMA Negeri 1 Sendawar dan SMA Negeri 1 Linggang Bigung Kabupaten Kutai Barat, peneliti dapat disimpulkan bahwa:

1. Pemanfaatan laboratorium fisika di SMA Negeri 1 Sendawar dan SMA Negeri 1 Linggang Bigung Kabupaten Kutai Barat tergolong dalam predikat kurang baik.

2. Kontribusi laboratorium fisika terhadap pembelajaran fisika di SMA Negeri 1 dan SMA Negeri 1 Linggang Bigung tergolong kurang berkontribusi terhadap pembelajaran fisika.

\section{DAFTAR PUSTAKA}

Arifin, I. (2017). Efektivitas Pemanfaatan Laboratorium IPA dalam Menunjang Pembelajaran di MI DAARUL AITAM Palembang. Palembang: Universitas Islam Negeri Raden Fatah Palembang.

Berliani, S. (2019). Analisis Staandardisasi Laboratorium Dalam Proses Pembelajaran Fisika (Studi Kasus di MAN 4 Aceh Besar). Aceh: Universitas Islam Negeri AR-RANIRY Banda Aceh.

Imastuti. (2016). Pemanfaatan Laboratorium Dalam Pembelajaran Fisika SMA/MA Se-Kota Salatiga. Semarang: Universitas Negeri Semarang.

Indrawan, I. (2015). Pengantar Manajemen Sarana dan Prasarana Sekolah. Deepublish.

Nursabiah dan Erniwati dan Yuris Muhammad. (2020). Kesiapan dan Pemanfaatan Laboratorium Pada Pembelajaran Fisika di SMK Negeri Se-Kabupaten Kolaka. Jurnal Penelitian Pendidikan Fisika, Vol. 5, Hal. 62.

Rohmi, A,. dan Delsina, F. (2019). Kontribusi Minat Belajar dan Pemanfaatan Sarana dan Prasarana Laboratorium Terhadap Hasil Belajar Siswa. Jurnal Vokasional Teknik Elektronika Dan Informatika, Vol. 7, No (2302-3295), 160.

Rukminingsih dan Adnan, Gunawan dan Latief, M. A. (2020). Metode Penelitian Pendidikan (1st ed.). Yogyakarta: Erhaka Utama.

Sari, Cintia Pinatih dan Roza, L. (2020). Hasil Analisis Kebutuhan Pemanfatan Laboratorium Fisika Sebagai Penunjang Hasil Belajar. Prosiding Seminar Nasional Fisika, Vol. 9, Hal. 2. 
Wahyunidar. (2017). Analisis Pemanfaatan Laboratorium Fisika Sebagai Sarana Kegiatan Praktikum di SMA Negeri Se-Kabupaten Luwu Timur. Makasar: UIN ALAUDIN MAKASAR.

Zikrika. (2015). Efektifitas Penggunaan Laboratorium IPA dalam Pembelajaran Biologi di SMP Negeri 3 Palembang. Palembang: UIN Raden Fatah Palembang. 